\title{
THE FIRST RECORD OF THE RARE AND THREATENED SAPROXYLIC COLEOPTERA, CUCUJUS CINNABERINUS (SCOPOLI, 1763), RHYSODES SULCATUS (FABRICIUS, 1787) AND OMOGLYMMIUS GERMARI (GANGLBAUER, 1891) IN KOPAČKI RIT NATURE PARK
}

\author{
Matej Šag ${ }^{1}$, Nataša Turić ${ }^{1}$, Goran Vignjević ${ }^{1}$, Boris LaUŠ ${ }^{2}$ \\ \& Martina Temunovićc ${ }^{3,4}$
}

${ }^{1}$ Department of Biology, Josip Juraj Strossmayer University, Cara Hadrijana 8/A, 31000 Osijek, Croatia (e-mail: msag@biologija.unios.hr)

${ }^{2}$ Croatian Herpetological Society - Hyla, I. Lipovac 7, 10000 Zagreb, Croatia

${ }^{3}$ Department of Forest Genetics, Dendrology and Botany, Faculty of Forestry, University of Zagreb, Svetošimunska 25, 10000 Zagreb, Croatia

${ }^{4}$ Association BIOM, Croatian Institute for Biodiversity, Preradovićeva 34, 10000 Zagreb, Croatia

Šag, M., Turić, N., Vignjević, G., Lauš, B. \& Temunović, M.: The first record of the rare and threatened saproxylic Coleoptera, Cucujus cinnaberinus (Scopoli, 1763), Rhysodes sulcatus (Fabricius, 1787) and Omoglymmius germari (Ganglbauer, 1891) in K0opački rit Nature Park. Nat. Croat., Vol. 25, No. 2., 249-258, Zagreb, 2016.

In 2014 research was carried out into saproxylic beetle fauna in different forest communities in Kopački rit Nature Park. There were 64 species of saproxylic beetles found in the area. Among them Cucujus cinnaberinus (Scopoli, 1763) and Rhysodes sulcatus (Fabricius, 1787) are protected by the European Habitats Directive (Annex II and IV of Council Directive 92/43/EEC) as well as by the Bern Convention (Annex II), and are listed in the IUCN Red List of Threatened Species. R. sulcatus and Omoglymmius germari (Ganglbauer, 1891), which was also determined, are also virgin forest relict species of Europewide importance. Additionally, we have used intercept traps, pitfall traps and air traps with attractants to estimate the relative abundance and seasonal activity of adults as well as to estimate trapping efficiency. Some morphological, biological and distributional features of these three species are discussed.

Key words: New records, threatened species, Cucujus cinnaberinus, Rhysodes sulcatus, Omoglymmius germari, NATURA 2000, relict species

Šag, M., Turić, N., Vignjević, G., Lauš, B. \& Temunović, M.: Prvi nalaz rijetkih i ugroženih saproksilnih kornjaša, Cucujus cinnaberinus (Scopoli, 1763), Rhysodes sulcatus (Fabricius, 1787) i Omoglymmius germari (Ganglbauer, 1891) u Parku prirode Kopački rit. Nat. Croat., Vol. 25, No. 2., 249-258, Zagreb, 2016.

Tijekom 2014. godine provedeno je istraživanje saproksilnih kornjaša unutar različitih šumskih zajednica na području Parka prirode Kopački rit. Utvrđena je prisutnost 64 vrste. Vrste Cucujus cinnaberinus (Scopoli, 1763) i Rhysodes sulcatus (Fabricius, 1787) navedene su u Direktivi o staništima (Dodatak II i IV Direktive 92/43/EEC) i Bernskoj konvenciji (Dodatak II) te se nalaze na IUCN-ovom crvenom popisu ugroženih vrsta. Vrste Rhysodes sulcatus i Omoglymmius germari (Ganglbauer, 1891) su reliktne vrste netaknutih šuma od europske i međunarodne važnosti. Za uzorkovanje su korištene barijerne klopke, lovne klopke $\mathrm{u}$ tlu te zračne klopke $\mathrm{s}$ atraktantom kako bi se procijenila relativna brojnost $\mathrm{i}$ sezonska aktivnost odraslih jedinki kao i učinkovitost navedenih metoda. U radu su prikazana neka morfološka i biološka obilježja kao i raprostranjenost ove tri vrste.

Ključne riječi: Novi nalazi, ugrožene vrste, Cucujus cinnaberinus, Rhysodes sulcatus, Omoglymmius germari, NATURA 2000, reliktne vrste 


\section{INTRODUCTION}

Saproxylic beetles are beetles that depend during some part of their life-cycle on living, dead or decaying wood (SPEIGHT, 1989). They are dependent on the dynamics of tree aging and are involved in the process of the fungal decay of wood or the products of that decay and thus play an important role in nutrient recycling in natural ecosystems (AlEXXNDER, 2008). They have been particularly affected by forest management and the degradation or loss of habitat quality, which are responsible for the species' decline. Saproxylic beetles make up one of the largest groups of red-listed species in many countries. The Republic of Croatia is also designated as an area with a large number of endangered species (Nieto \& Alexander, 2010).

A number of methods are commonly used for sampling in scientific studies of saproxylic beetles and each of them produces different capture results with regards to the species spectrum (RANiUS \& JANSSON, 2000; RANiUs, 2001; RANIUS \& JANSSON, 2002).

There has been no previous research into this ecological group of organisms in this eastern part of Croatia. However, Cucujus cinnaberinus (Scopoli, 1763) has so far been found only five times in Croatia. From the old literature it is known from the area of Medvednica Mountain (Hirc, 1905) and from Slavonia (old synonym Cucujus sanguinolentus Linnaeus, 1767) (SCHLOSSER, 1877; Horion, 1960). The first recent findings of populations in 2009 and later, were in northern Croatia in alluvial forests (A. Kapla and L. Šerić Jelaska, pers. comm.), in Zagreb, Grmošćica Forest Park (Boris Lauš, pers. comm.) and from Lubenovac, Sjeverni Velebit National Park (Boris Hrašovec, pers. comm., 2008, 2009 , three specimens found in pheromone traps for monitoring the spruce bark beetle).

In Croatia historical records for Rhysodes sulcatus (Fabricius, 1787) exist in the area of Mala and Velika Kapela (Reitrer, 1879), in Zagreb and Karlovac (Schlosser, 1877), Dilj and Papuk mountain, and also from Vinkovci (KočA, 1900, 1905). For Omoglymmius germari (Ganglbauer, 1891; old synonym Rhysodes exaratus Illig.) the only records come from Križevci and Đakovo (Schlosser, 1877).

Identifying, protecting and monitoring areas that support a high number of rare or threatened species is essential in conservation (ANDERsson et al., 2014). The saproxylic beetle fauna has been poorly studied in Kopački rit, one of the largest floodplains in Europe. It is designated as an area of international importance within the NATURA 2000 ecological network. Therefore, it is crucial to investigate the fauna of this ecological group since nowadays its distribution is under threat of extinction caused by fragmentation and habitat changes.

\section{MATERIAL AND METHODS}

The fieldwork was performed from April to October 2014. There were three sampling sites within three different forest communities (Fig. 1). The first site (A) was within an oak (Quercus robur L.) and hornbeam (Carpinus betulus L.) forest (As. Carpino betuli-Quercetum roboris "typicum" Rauš 1975). This area is out of the reach of flooding and it is an indicator of a typical terrestrial habitat (SPRINGER et al., 2003). Based on the National Habitat Classification of the Republic of Croatia (NKS) (SINP, 2009) mixed forests of oak and hornbeam are the most important forest community of the planar vegetation belt that develops out of the reach of flood waters. The second site (B) was on higher and better drained positions with stands of rare forests of white poplar (Populus alba L.) and black poplar (Populus nigra L.) (As. Populetum nigro-albae Slavnić 1952). This forest com- 


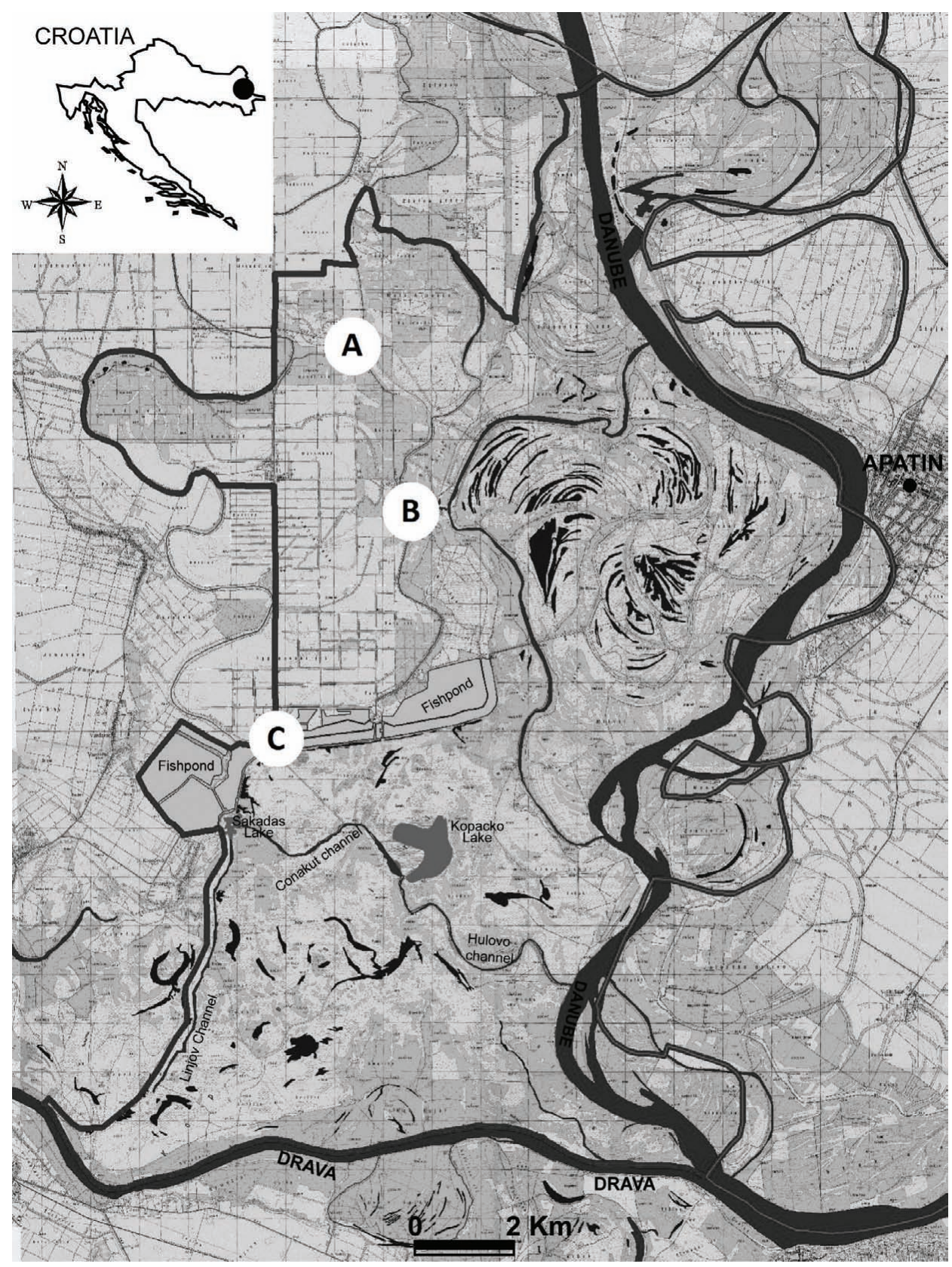

Fig. 1. Study area in the Danube floodplain (Kopački rit Nature Park, Croatia). White circles mark sampling sites (A Tikveš, B Wasteland Tikveš, C Danube ponds)

munity of poplar develops in the part of the floodplain where flooding last only for a short time (SPRINGER et al., 2003). The third site (C) included the fragment of community of white willow (Salix alba L.) and fragile willow (Salix fragilis L.) forest with blackberry 
(As. Salicetum albo-fragilis Soó (1930) 1958; Rubeto-Salicetum albae). This area was fully dried or periodically flooded on the pond side due to the high temperature during the seven months of research.

We used four sampling methods in combinations (window flight-intercept trap: cross-vanes and single-plane, pitfall trap and air trap with attractant). The cross-vane window flight trap consisted of two transparent panels of plexiglass placed crosswise (49 $\mathrm{cm} \times 17 \mathrm{~cm}$ ) with a container fixed below them. A single-plane window flight trap was made of mosquito netting $(46 \mathrm{~cm} \times 40 \mathrm{~cm})$ mounted above a container. The latter two traps were placed $150 \mathrm{~cm}$ above the ground fixed to a wooden support (Fig. 2). Apreservation mixture consisting ethanol:water 1:1 was used. Pitfall traps were cut in half $2 \mathrm{~L}$ plastic bottles (10 cm diameter) placed in rotten trunks, stumps or holes in trees. Those traps were filled with ethanol, water and vinegar (1:1:1). The same way of making bottles as the latter was used for the air trap with attractant method. Those traps were hung on trees $150 \mathrm{~cm}$ above ground and filled with red wine (Fig. 3). In every trap detergent was added to reduce the surface tension, which meant that the beetles trapped remained in the container. The traps were placed from April $16^{\text {th }}$ to October $10^{\text {th }} 2014$ during the main flight period of saproxylic beetles (Buse et al., 2010). Per site six traps were set of each type of trap in a linear transect. There were in all 24 traps per site used in this study. Collected specimens were fixed in $70 \%$ ethanol, dried, pinned and identified. The following keys were used for the identification: Bonacci et al. (2012), BeLl \& Bell (1978, $1979,2002,2009)$. All specimens were labelled and stored at the Josip Juraj Strossmayer University of Osijek, Department of Biology.
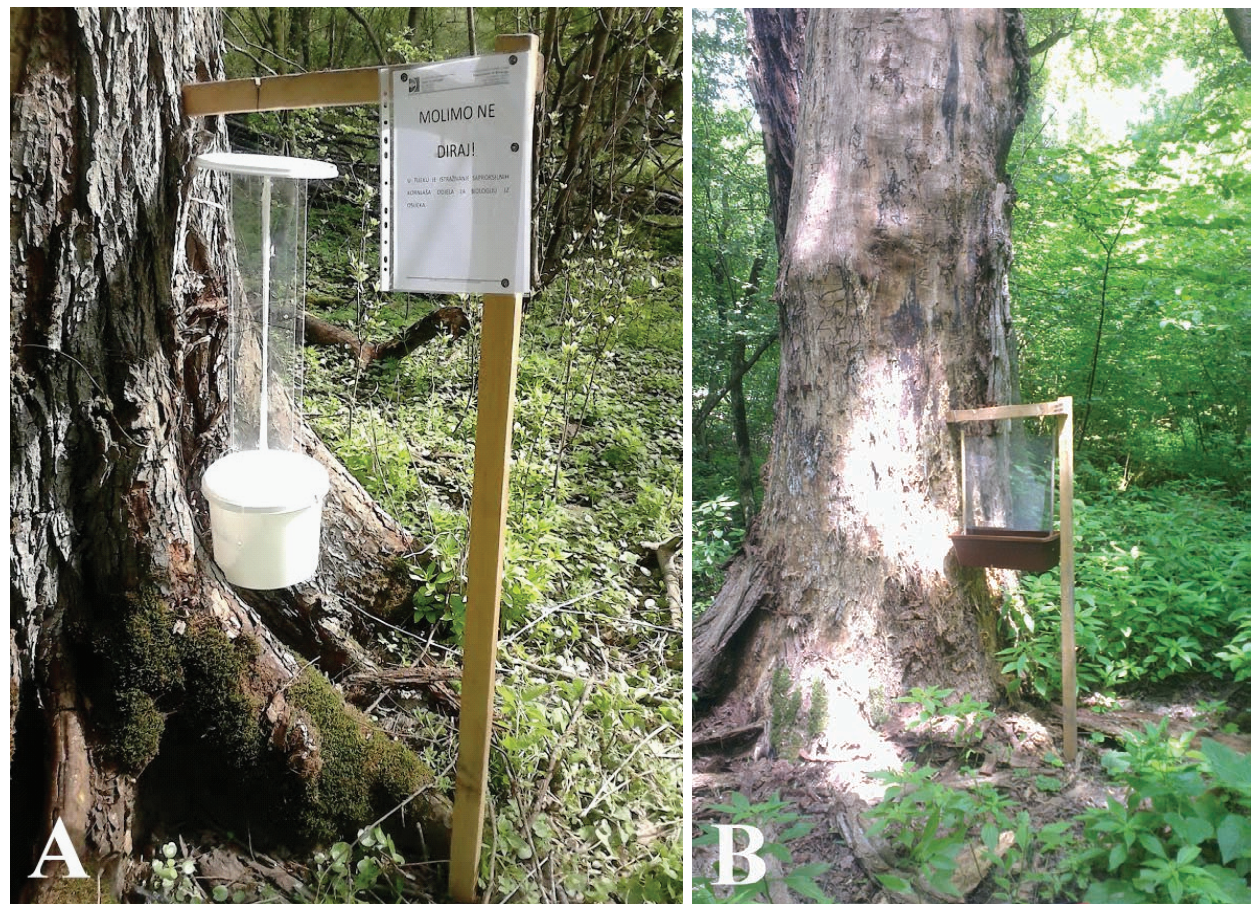

Fig. 2. Window flight-intercept traps: a cross-vanes (A) and a single-plane trap (B) on researched sites. 


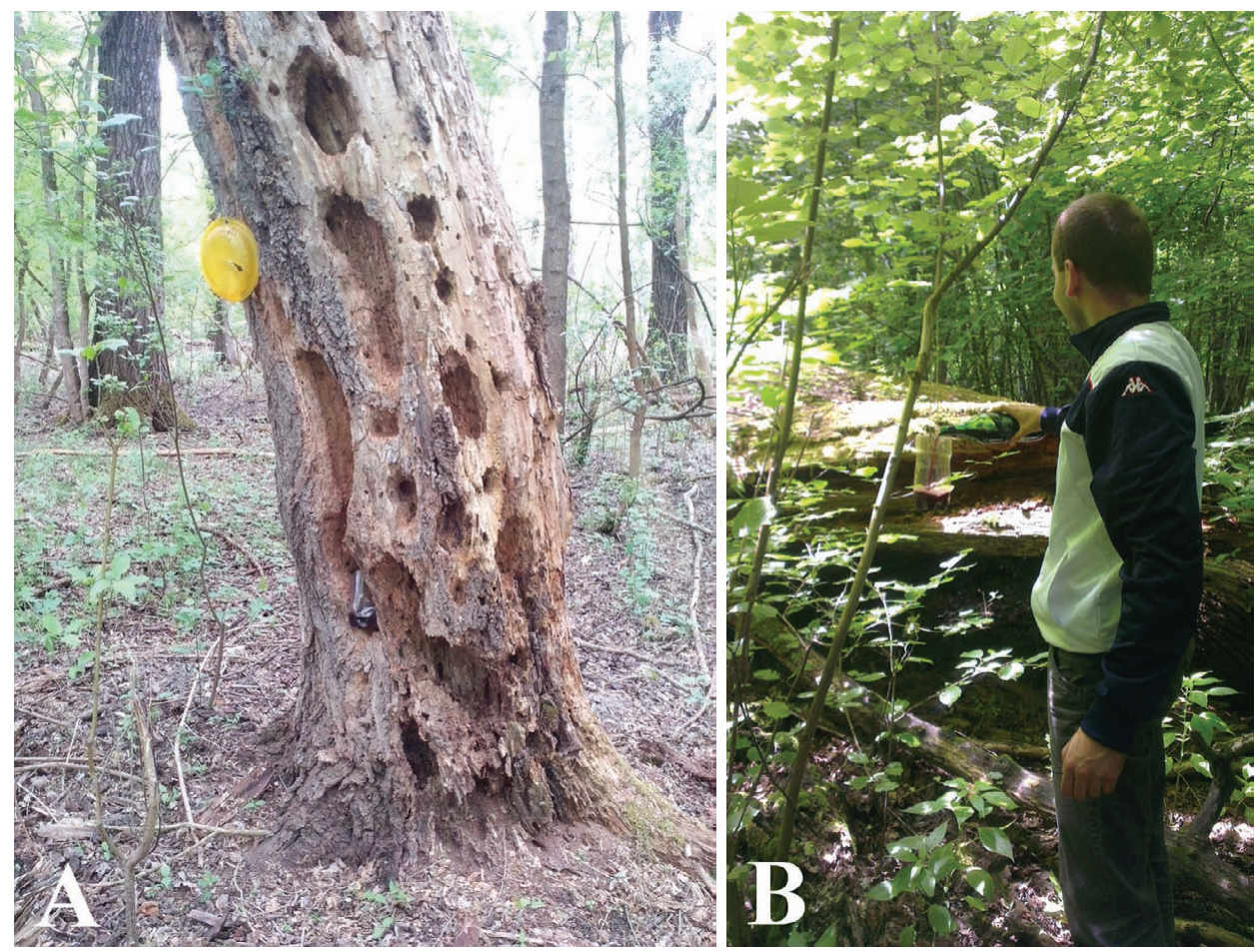

Fig. 3. Pitfall trap (A) set in holes of rotten trunk and air trap with attractant (B) hung on tree.

\section{RESULTS AND DISCUSSION}

\section{Cucujus Fabricius, 1775}

\section{Cucujus cinnaberinus (Scopoli, 1763)}

Material examined: Croatia, Osijek-Baranya County, Kopački rit Nature Park, 15 km NE of Osijek, Tikveš: 4541'48.08"'S 18²99'33.37'I, 29.04.2014, 2 specimens, oak and hornbeam forest, flight-intercept trap (cross-vanes), leg. Turić \& Šag, det. Turić \& Šag; Wasteland Tikveš: 4540'1.23"S 1850'57.23"I, 16.04.2014, 1 specimen, white and black poplar forest, flight-intercept trap (single-plane) 29.04.2014, 1 specimen, white and black poplar forest, flight-intercept trap (cross-vanes), leg. Turić \& Śag, det. Turić \& Šag.

Remarks: In Europe six species from the family Cucujidae occur (NiEto et al., 2010). C. cinnaberinus is one of two species from a family endemic to Europe (BonAcci et al., 2012) and one of the rarest beetles in Europe and its populations are thought to be declining in several European countries (Mazzer et al., 2011). Considering this, it is facing a high risk of extinction in the wild (GuÉorguiev et al., 2008). Its populations are more densely distributed only in Eastern Europe, from Austria and Bavaria eastwards (Horák \& Сновот, 2009). In Italy it has been thought that the beetle was extinct after 1960 but in the last decade it has been found in several regions (Biscaccianti et al., 2009; MAzzei et al., 2011). Also, this rare and endangered saproxylic species was recently recorded as more common and probably less threatened than had been thought and it is possibly even going through a phase of expansion (Bussler, 2002; SCHLAGHAMERsKý et al., 2008; 

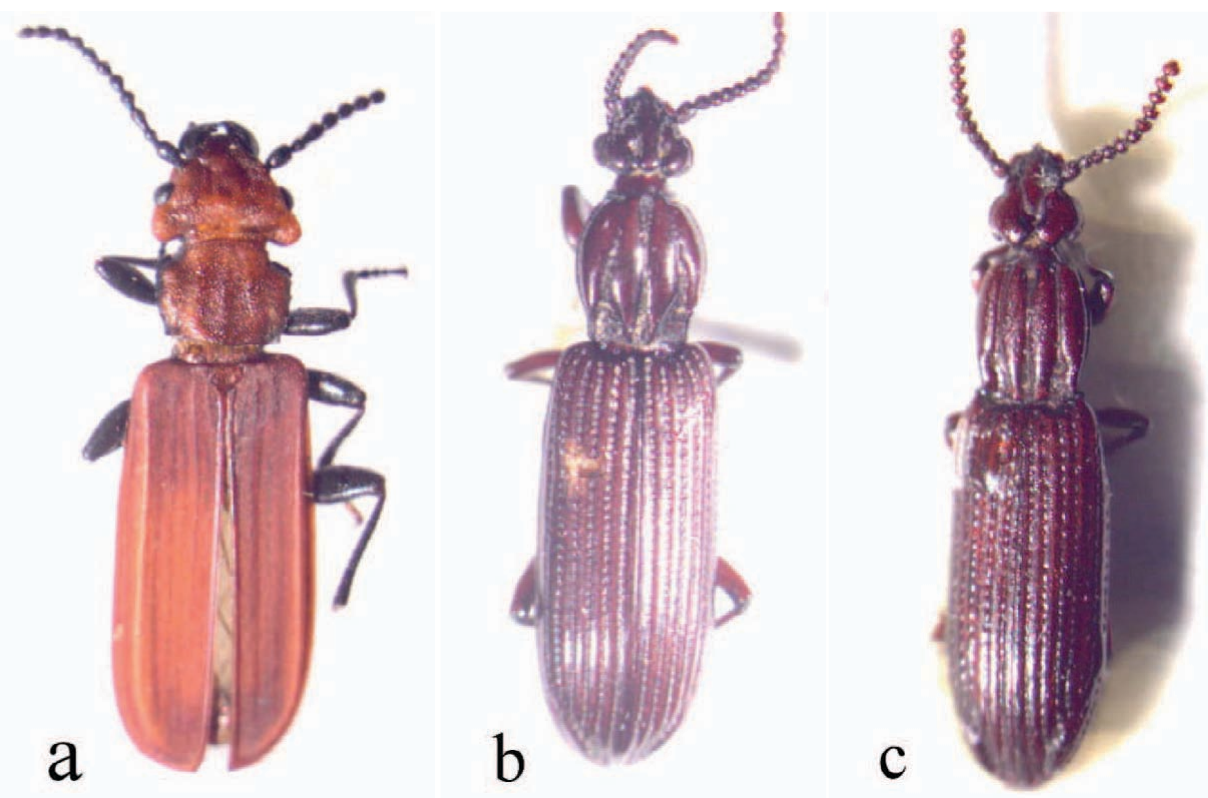

Fig. 4. Habitus, dorsal view of a) Cucujus cinnaberinus, b) Rhysodes sulcatus, c) Omoglymmius germari

MAzzei et al., 2011). This species is relatively widespread in central Europe - 90 localities in the Czech Republic, in Slovakia more than 100, in Hungary 55 and in Germany 33 (only in Bavaria). Populations of this species decline at the edge of its range. In Sweden there are 3 contemporary localities (historically 9), in Finland 2 (historically 9), in Estonia 3 (historically 5). The species was considered probably extinct in Croatia and in the southern parts of the former Yugoslavia (SLIPINSKI, 2004; Horák et al., 2008) until these recent records in Kopački rit Nature Park. As Croatia only has a monitoring scheme for Lucanus cervus among the annex species it is not possible to describe the population trend in the country (Dražina \& TEMunović, 2011; ŠERIĆ JELASKA, 2013). Also, forest management in this area of Kopački rit is satisfactory because all the trunks were in the same places during the research and there were no visible traces of the removal of dead trunks or logs. Nevertheless, in other European countries a decline in population accompanies the loss of habitats with diversified stands and ample dead wood (НоRÁк et al., 2008).

The occurrence of this species is a basis for the creation of areas within the NATURA 2000 network. It is difficult to locate adults because their seasonal activity is short and limited to $2-3$ months per year (Gutowski et al., 2014). Despite this, larvae are easy to find throughout the whole year in the lying or standing dead trees of various species (НовÁк \& Сновот, 2011; Gutowsкi et al., 2014). There are still many gaps in current knowledge about the ecology of the species, knowledge that is a prerequisite for effective conservation management. This species is defined as a potential umbrella species for the protection of natural habitats with a large amount of dead wood and protection for other species sharing the same habitat (Horák et al., 2008; Mazzei et al., 2011).

The larval stages of Cucujus develop in two years (PALM, 1959) and the pupae appear in July in small holes dug out in the decaying bast. The adults emerge after 15 days and 
remain hidden in the bark for months (НовÁк \& Сновот, 2011). They appear on the trees the year after and fly actively from the second half of April until the end of May (ScHLAGHAMERSKÝ et al., 2008; VREZEC et al., 2012) or June (Bussler, 2002). Thus the peak of activity is estimated to be from $15^{\text {th }}$ April to $31^{\text {st }}$ May. This correlates positively with our findings since all four specimens were caught in April.

Body length of $C$. cinnaberinus is $12-15,5 \mathrm{~mm}$. Head is triangular, wider than pronotum, sides of pronotum, inner side of postgenae and mandibles are black (Fig. 4a). Maximum width of the pronotum at the front border, ventral side of the same part black, with a median yellow stripe that is prolonged to the prosternal apophysis. Antennae without club (GuÉorguiev et al., 2008; BonaCCI et al., 2012).

\section{Rhysodes Dalman, 1823}

\section{Rhysodes sulcatus (Fabricius, 1787)}

Material examined: Croatia, Osijek-Baranya County, Kopački rit Nature Park, 15 km NE of Osijek, Tikveš: 4541'48.08"'S 18²99'33.37"I, 29.04.2014, 1 specimen, oak and hornbeam forest, flight-intercept trap (cross-vanes), leg. Turić \& Šag, det. Turić \& Šag.

Remarks: The history of the extinction of the species in west and central Europehas been documented (SPEIGHT, 1989). Intensive logging and forest management in many parts of Europe caused local extinction (VREzec et al., 2009). The species' larval development take place in rottening tree trunks of both deciduous and coniferous trees and of many different tree species, such as silver fir (Abies alba), spruce (Picea abies), beech (Fagus sylvatica), aspen (Populus tremula) and oak (Quercus sp.) (BuraKowsкi, 1975; Bussler et al., 2005). As the species lives in relatively wet and rotten trunks the humidity in the wood seems more important than tree species. Adult beetles overwinter under the bark or in the wood, often in the tunnels of other species, such as the larvae of Ceruchus chrysomelinus (Hochenwart, 1785). Since this is a lesser known, very rare and vanishing beetle it is not surprising that it was collected only once during a whole season. This species is associated with natural and primeval forests, mostly deciduous and mixed forests. R. sulcatus has the highest demand on biotope tradition and original forests at a landscape level (Bussler et al., 2005). Adult beetles and larvae of R. sulcatus can live within small groups. Mating of this species takes place between May and September (VREzec et al., 2009) when the adults start to be more active. This correlates with our findings of activity from the middle till the end of April. The larvae live two years in the rotten wood tunnels (BURAKOWSKI, 1975). Adults of this species are nocturnal, although some researchers have found them on dead tree trunks during the day (VREZEC, 2007).

The body of this beetle is narrow and cylindrical with a length of $6.8-8.3 \mathrm{~mm}$ (Fig. $4 b)$. They are dark brown to black in color to reddish, smooth. The antennae are moniliform and antennal segment XI is slightly less than twice as long as wide. Head is relatively small with protuberant eyes. Pronotum is relatively short and broad with three grooves, of which two external from the front shortened. Elytras are punctated. The legs are relatively short and dark colored (SCHLOsser, 1877; BeLl \& BeLl, 1979).

\section{Omoglymmius Ganglbauer, 1892}

\section{Omoglymmius germari (Ganglbauer, 1891)}

Material examined: Croatia, Osijek-Baranya County, Kopački rit Nature Park, 15 km NE of Osijek, Tikveš: 4541'48.08'S 18²49'33.37'I, 29.05.2014, 1 specimen, oak and hornbeam forest, flight-intercept trap (cross-vanes), leg. Turić \& Šag, det. Turić \& Šag; Wa- 



plar forest, flight-intercept trap (cross-vanes), 6 specimens, white and black poplar forest, flight-intercept trap (single-plane), 24.06.2014, 1 specimen, white and black poplar forest, flight-intercept trap (single-plane), leg. Turić \& Sag, det. Turić \& Šag.

Remarks: The genus Omoglymmius includes about 50 species, and 5 of them inhabit the Palearctic region. Omoglymmius germari is the only species found so far in Central and South Europe. The species is discovered in old, fallen trunks of deciduous trees and is considered a virgin forest relict species (Bussler et al., 2005; BEKCHIEv, 2010). This species is also known from Azerbaijan, Armenia, Austria, Bulgaria, France, Georgia, Greece, Hungary, Italy, Moldavia, Poland, Romania, Slovakia, Russia (Southern European Territory) and Ukraine; in Asia it is known only from Iran and Turkey (NiLsson, 2003). It is included in the IUCN Red List of saproxylic species as data deficient (DD) species (Nieto \& AleXANDer, 2010). In contrast to $R$. sulcatus this species seems to be associated more strongly with river valleys and floodplains (BussLer et al., 2005). This coincides with our results since 9 specimens were found in forests of white and black poplar (Populetum nigro-albae) along the Čarna channel. Only one specimen was found in oak and hornbeam forest, which can be correlated with the many trunks and logs and the amount of dead wood mass (RANius \& JANSSON, 2002; LACHAT et al., 2012; VodKA \& CizeK, 2013). Both Rhysodes and Omoglymmius are relict species specific to virgin forests and considered to be now extinct in Western Europe (Bussler et al., 2005; BEKCHIEv, 2010).

The body of this beetle is very similar to that of $R$. sulcatus, narrow and cylindrical with length $6.8-8.3 \mathrm{~mm}$ (Fig. 4c). They are dark-reddish-brown, smooth. The antennae are moniliform. Head is relatively small with protuberant eyes. Pronotum is relatively short and broad with three grooves. Median and paramedian grooves deep, distinct and complete. Strial punctures various, from coarse to very fine, middle and hind tibiae each with single spur (BELL \& BeLL, 1978, 1979).

Saproxylic insect species are useful in identifying forests of international importance for conservation (Speight, 1989; Good \& SPEIGHT, 1996). Likewise, saproxylic beetles are highly sensitive to forest management practices that reduce the abundance and variety of dead wood (Ulyshen \& Hanula, 2009). Our results indicate, that the occurrences of these three valuable species in Kopački rit Nature Park were the result of forest management principles that in this area restrict any actions that could negatively affect biodiversity. Trunks that were found there are suitable microhabitats with a lot of dead wood, which contributes to the greater abundance and species richness of threatened saproxylic beetles.

These results present valuable data since these are the first records of those species in Kopački rit and also the most recent records for Croatia. None of the three species in this paper are noted in Catalogues of Palearctic Coleoptera (NiLsson, 2003; Muona, 2007) as occurring in Croatia or even in the online database Fauna Europaea (DE Jong et al., 2014).

Received February 17, 2016

\section{REFERENCES}

Alexander, K. N. A., 2008: Tree biology and Saproxylic Coleoptera: Issues of definitions and Conservation Language. Revue d'écologie (la Terre et la Vie) 63, 1-5.

Andersson, K., Bergman, K. O., Andersson, F., Hedenström, E., Jansson, N., Burman, J., Winde, I., Larsson, M. C. \& Milberg, P., 2014: High-accuracy sampling of saproxylic diversity indicators at regional scales with pheromones: The case of Elater ferrugineus (Coleoptera, Elateridae). Biological Conservation 171, 156-166. 
Bell, R. T. \& Bell, J. R., 1978: Rhysodini of the world. Part I. A new classification of the tribe, and a synopsis of Omoglymmius subgenus Nitiglymmius, new subgenus (Coleoptera: Carabidae or Rhysodidae). Quaestiones Entomologicae 14, 43-88.

Bell, R. T. \& Bell, J. R., 1979: Rhysodini of the world. Part II. Revisions of the smaller genera (Coleoptera: Carabidae or Rhysodidae). Quaestiones Entomologicae 15, 377-446.

Bell, R. T. \& Bell, J. R., 2002: Two new species of Rhysodini (Coleoptera: Carabidae) with revised keys to Yamatosa Bell \& Bell and Omoglymmius (Pyxiglymmius) Bell \& Bell. Stuttgarter Beiträge zur Naturkunde, Serie A (Biologie) 636, 1-7.

Bell, R. T. \& Bell, J. R., 2009: Rhysodine beetles (Insecta: Coleoptera: Carabidae): new species, new data III. Annals of Carnegie Museum 78, 45-77.

Biscaccianti, A., Audisio, P. \& Monguzzi, R., 2009: Aggiornamenti sulla distribuzione di Cucujus cinnaberinus e altri Cucujoidea (Coleoptera: Nitidulidae, Cucujidae, Laemophloeidae). Bollettino dell' Associazione Romana di Entomologia 63(1/4), 47-57.

Bonacci, T., Mazzei, A., Horák, J. \& Brandmayr, P., 2012: Cucujus tulliae sp. n. - an endemic Mediterranean saproxylic beetle from genus Cucujus (Fabricius, 1775) (Coleoptera, Cucujidae), and keys for identification of adults and larvae native to Europe. ZooKeys 212, 63-79.

Burakowski, B., 1975: Descriptions of larva and pupa of Rhysodes sulcatus (F.) (Coleoptera, Rhysodidae) and notes on the bionomy of this species. Annales Zoologici 32(12), 271-287.

Buse, J., Levanony, T., Timm, A., Dayan, T., Assmann, T., 2010: Saproxylic beetle assemblages in the Mediterranean region: Impact of forest management on richness and structure. Fores Ecology and Management 259, 1376-1384.

Bussler, H., 2002: Untersuchungen zur Faunistik und Ökologie von Cucujus cinnaberinus (Scop., 1793) in Bayern (Coleoptera: Cucujidae). Nachrichtenblatt der Bayerischen Entomologen 51, 42-60.

Bussler, H., Müller, J. \& Dorka, V., 2005: European natural heritage: the saproxylic beetles in the proposed National Park Defileul Jiului. Anale ICAS 48(1), 55-71.

DE JonG, Y. et al., 2014: Fauna Europaea - all European animal species on the web. Biodiversity Data Journal 2: e4034. doi: 10.3897/BDJ.2.e4034.

Dražına, T. \& Temunović, M., 2011: Istraživanja ciljnih Natura 2000 vrsta kornjaša u parku Maksimir. Konačni izvještaj. Udruga za biološka istraživanja - BIOM, Zagreb. pp. 24.

Good, J. A. \& Speight, M. C. D., 1996: Saproxylic invertebrates and their conservation through Europe. Convention on the Conservation of European Wildlife and Natural Habitats, Council of Europe. pp. 58.

Guéorguiev, B., Doychev, D. \& Ovcharov, D., 2008: Cucujidae (Coleoptera: Cucujoidea) - a new family to the fauna of Bulgaria. Historia naturalis bulgarica 19, 93-97.

Gutowski, J. M., Kadej, M., Smolis, A. \& TARnAwski, D., 2014: Identification of Larvae of Endangered Cucujus cinnaberinus and C. haematodes (Coleoptera: Cucujidae). Journal of Insect Science 14(228), 1-7.

Hirc, D., 1905: Prirodni zemljopis Hrvatske, Knjiga prva: Lice naše domovine. Zagreb. pp. 170.

Нови́к, J. \& Сновот, K., 2011: Phenology and notes on the behaviour of Cucujus cinnaberinus: points for understanding the conservation of the saproxylic beetle. North-Western Journal of Zoology 7(2), 352355.

HorÁк, J., \& Сновот, K., 2009: Worldwide distribution of saproxylic beetles of the genus Cucujus Fabricius, 1775 (Coleoptera: Cucujidae). In: Buse J, Alexander KNA, Assmann T (Eds) Saproxylic beetles - Their role and diversity in European woodland and tree habitats. Pensoft Publishers, Sofia-Moscow. p. 189-206.

Horák, J., Сновот, K., КонutкA, A. \& Gebauer, R., 2008: Possible factors influencing the distribution of a threatened saproxylic beetle Cucujus cinnaberinus (Scopoli 1763) (Coleoptera: Cucujidae). The Coleopterists Bulletin 62, 437-440.

Horion, A., 1960: Faunistik der Mitteleuropäischen Käfer, Band VII, Clavivornia, 1. Teil, (Sphaeritidae bis Phalacridae). Kommissionsverlag Buchdruckerei Aug. Feyel. p. 170-172.

KočA, GJ., 1900: Prilog fauni gore Papuka i njegove okoline. Glasnik hrvatskog naravoslovnog društva 12(1-3), 100-134.

KočA, GJ., 1905: Popis tvrdokrilaca (kornjaša) vinkovačke okolice. Glasnik hrvatskog naravoslovnog društva 17.

Lachat, T., Wermelinger, B., Gossner, M. M., Bussler, H., Isacsson, G. \& Müller, J., 2012: Saproxylic beetles as indicator species for dead-wood amount and temperature in European beech forests. Ecological Indicators 23, 323-331. 
Mazzei, A., Bonacci, T., Contarini, E., Zetto, T. \& Brandmayr, P., 2011: Rediscovering the 'umbrella species' candidate Cucujus cinnaberinus (Scopoli, 1763) in Southern Italy (Coleoptera Cucujidae), and notes on bionomy. Italian Journal of Zoology 78(2), 264-270.

Muona, J., 2007: Cucujidae, pp. 502-503. - In Löвl, I. \& Smetana, A. (ed.): Catalogue of Palaearctic Coleoptera, Vol. 4. Stenstrup: Apollo Books. pp. 935.

Nieto, A., Alexander, K. N. A., 2010: European Red List of Saproxylic Beetles. Publications office of the European Union, Luxembourg. pp. 46.

Nieto, A., Mannerkoski, I., Putchkov, A., Tykarski, P., Mason, F., Dodelin, B., Horák, J. \& Tezcan, S., 2010: Cucujus cinnaberinus. The IUCN Red List of Threatened Species 2010:e.T5935A11921415. http:// dx.doi.org/10.2305/IUCN.UK.2010-1.RLTS.T5935A11921415.en.

Nilsson, A. N., 2003: Rhysodidae, pp. 78-79 - In: I. Lobl \& A. Smetana (editors): Catalogue of Palaearctic Coleoptera. Vol. 1. Stenstrup: Apollo Books. pp. 819.

PAlm, T., 1959: Die Holz- und Rindenkäfer der Süd- und Mittelschwedischen Laubbäume [The wood and bark Coleoptera of deciduous trees in southern and central Sweden] (in German, English Summary). Opuscula Entomologica Supplementum 16, 1-374.

RAnius, T., 2001: Constancy and asynchrony of populations of a beetle, Osmoderma eremita living in tree hollows. Oecologia 126, 208-215.

Ranius, T. \& JANsson, N., 2000: The influence of forest regrowth, original canopy cover and tree size on saproxylic beetles associated with old oaks. Biological Conservation 95, 85-94.

RANiUs, T. \& JANSSON, N., 2002: A comparison of three methods to survey saproxylic beetles in hollow oaks. Biodiversity and Conservation 11, 1759-1771.

Reitter, E., 1879: Coleopterologische Ergebnisse einer Reise nach Croatien und Slavonien. Verhandlungen der kaiserlich-königlichen zoologisch-botanischen Gesellschaft 29, 35-56.

Schlaghamerský, J., Maňák, V. \& Čechovský, P., 2008: On the mass occurrence of two rare saproxylic beetles, Cucujus cinnaberinus (Cucujidae) and Dircaea australis (Melandryidae), in South Moravian floodplain forests. Revue d'Ecologie (la Terre et la Vie) 63, 107-113.

Schlosser, J. K., 1877. Fauna kornjašah Trojedne kraljevine, Svezak prvi. Jugoslavenska akademija znanosti i umjetnosti. Zagreb. p. 288-290.

Slipinski, S. A., 2004: Fauna Europaea: Cucujidae. - In: Audisio P. (ed.). Fauna Eureopaea: Coleoptera 2, Beetles. Fauna Europaea, version 1.3., last update 19 April 2007.

Speight, M. C. D., 1989: Saproxylic invertebrates and their conservation. Council of Europe. Nature and Environment 42, pp. 79.

Springer, O. P., Mihaljević, M., Getz, D., Božičević, S., Bognar, A., Topić, J., Merdić, E. \& Krčmar, S., 2003: Kopački rit - Park prirode: ekološki turistički vodič. Barbat. Zagreb. Ministarstvo zaštite okoliša i prostornog uređenja RH, Barbat, Zagreb. pp. 89.

ŠERIĆ JELASKA, L., 2013: Terensko ispitivanje učinkovitosti metoda za praćenje stanja populacija jelenka (Lucanus cervus) predloženih u monitoring programu izrađenom u okviru IPA MANMON projekta (Natura 2000 Management and Monitoring, Croatia EuropeAid/129747/D/SER/HR). Biološki odsjek, Prirodoslovno-matematički fakultet Sveučilišta u Zagrebu. p. 26.

Ulyshen, M. D. \& Hanula, J. L., 2009: Habitat associations of saproxylic beetles in the southeastern United States: A comparison of forest types, tree species and wood postures. Forest Ecology and Management 257, 653-664.

VodkA, S. \& CizeK, L., 2013: The effects of edge-interior and understorey-canopy gradients on the distribution of saproxylic beetles in a temperate lowland forest. Forest Ecology and Management 304, 33-41.

Vrezec, A., 2007: Status brazdarja (Rhysodes sulcatus) v Sloveniji (Coleoptera: Rhysodidae): dosedanje poznavanje in raziskovalne perspective. Acta entomologica slovenica 15(1), 51-56.

Vrezec, A., Ambrožič, Š. \& Kapla, A., 2012: An overview of sampling methods tests for monitoring schemes of saproxylic beetles in the scope of NATURA 2000 in Slovenia. Saproxylic beetles in Europe: monitoring, biology and conservation 79-90.

Vrezec, A., Ambrožič, Š., Polak, S., Pirnat, A., Kapla, A. \& Denac, D., 2009: Izvajanje spremljanja stanja populacij izbranih ciljnih vrst hroščev v letu 2008 in 2009 in zasnova spremljanja stanja populacij izbranih ciljnih vrst hroščev. Carabus variolosus, Leptodirus hochenwartii, Lucanus cervus, Morinus funereus, Rosalia alpina, Bolbelasmus unicornis, Stephanopachys substriatus, Cucujus cinnaberinus, Rhysodes sulcatus. - Nacionalni inštitut za biologijo, Ljubljana. p. 174. 